\title{
Monimuoto-opetuksen kehittäminen aikuiskoulutuksessa
}

Opetushallituksen aikuiskoulutuksen linja tukee voimakkaasti monimuoto-opetuksen lisäämistä suomalaisessa aikuiskoulutuksessa. Se on käynnistänyt tätä varten monimuoto-opetuksen kehittämiskeskuksia viidelle paikkakunnalle eri puolille Suomea.

\section{Mitä monimuoto-opetuksella tarkoitetaan?}

Monimuoto-opetuksen käsitteistö on vielä melko vakiintumaton. Suomessa on viime vuosina käytetty yleiskäsitteitä monimuoto-opetus ja etäopetus; kahdeksankymmenluvun alkupuolelle saakka termiä etäopetus ja sen jälkeen melko vakiintuneesti termiä monimuoto-opetus.

Suomalaisen koulutuksen kentällä monimuoto-opetuksella tarkoitetaan toisinaan hallinnollisia ja organisatorisia opetuksen järjestelytapoja, toisinaan didaktisia ja pedagogisia (andragogisia) järjestelytapoja, joiden avulla edistetään aikuisten oppimista. Monimuoto-opetukseen kytkeytyy läheisesti opetuksen monivälineisyys.

Monimuoto-opetuksen käsitteen "virallistuminen" tapahtui 1989, kun aikuiskoulutusneuvosto määritteli monimuoto-opetuksen seuraavasti:
Monimuoto-opetuksella tarkoitetaan tietylle kohderyhmälle suunnitelmalliseksi kokonaisuudeksi yhdistettyä lähi- ja etäopetusta sekä itseopiskelua, joita tukee opiskelijan objaus ja neuvonta. Monimuoto-opetuksessa käytetään tarvittaessa hyväksi säbköistä viestintätekniikkaa. Opetusta voivat järjestää useat aikuiskoulutusorganisaatiot yhteistyössä.

Ammatillisissa oppilaitoksissa monimuotoopetusta on järjestetty lähinnä kokeiluina vuodesta 1986 alkaen. Monimuotoisen opetuksen toteuttaminen ei ole vielä niin yleistä kuin on tavoitteena, vaikka mitään säädöksellisiä esteitä ei enää ole olemassa. Vuonna 1987 tuli voimaan uusi oppilaitoslainsäädäntö, jonka mukaan kaikki ammatilliset oppilaitokset voivat järjestää myös etäopetusta. Oppilaitos ratkaisee kutakin alkavaa ryhmää varten laatimassaan oppilaitoskohtaisessa opetussuunnitelmassa, millaisia opetusjärjestelyjä kulloinkin käytetään opetustavoitteiden saavuttamiseksi. Lisäksi oppilaitos joutuu laatimaan kullekin aikuisopiskelijalle henkilökohtaiset opiskelusuunnitelmat.

Voisivatko siis opetuksen monimuotoistamisen esteet piillä opettajien totutuissa työskentelytavoissa ja ehkä vanhanaikaisissa oppimiskäsityksissä? Toisaalta on toki todettava, etteivät nykyisin voimassa olevat opetussuunnitelman perusteet (joita tosin ollaan uudistamassa), jäykät rahoituskuviot tai palvelussuhteen ehdot tee mitenkään helpoksi monimuotoisen opetuksen toteuttamista.

Kokeiluja on ollut monissa oppilaitosmuodoissa, mutta ne ovat alkuvaiheessa olleet melko suppeita yhden tai muutaman oppilaitoksen hankkeita. Tiedon levittäminen kokeiluissa saavutetuista ratkaisuista ja ratkaisujen laajentaminen jokapäiväiseksi käytännöksi on ollut ongelmallista. 


\section{Kokemuksia}

\section{kehittämishankkeista}

Mainitut kokeilut ovat jo päättyneet tai päättymässä ja niistä on kerätty tietoa uusien kehittä- mishankkeiden ratkaisujen ja selvitystehtävien pohjaksi. Päättyneitä kokeiluja ja niistä saatuja kokemuksia voidaan tarkastella seuraavan jaottelun mukaisesti:

\section{MONIMUOTO-OPETUS \\ - tavoitteena tutkinto tai opintokokonaisuus}

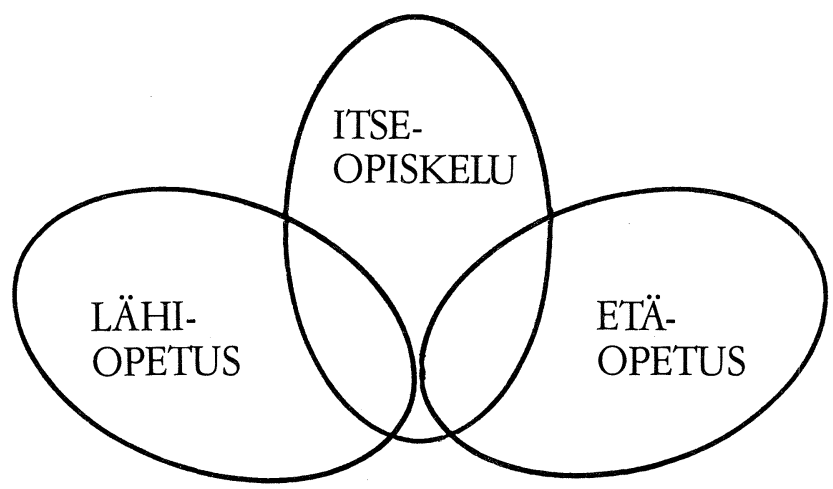

On huomattava, että pelkkä etäopetus ei ole monimuoto-opetusta ja että oppimistuloksista vastaa viime kädessä opiskelija itse, niin lähi- kuin etäopetuksessakin.

Päättyneistä monimuotokokeiluista on saatu mm. seuraavia kokemuksia:

\section{Lähiopetus}

* Lähiopetuksen toteutuksessa on saatu alkuun oppilaitosten yhteistoimintaa koulutuksen organisoimiseksi, on saatu tietoa yhteistyön esteenä olevista seikoista ja niiden selvittäminen on siten pystytty aloittamaan.

\section{Etäopetus}

* Etäopetusosuutta varten on kokeilujen yhteydessä valmistunut materiaalia, jota on voitu levittää valtakunnallisesti (mm. kaupan alat).

* On saatu kokemuksia sähköisten viestinten käyttökelpoisuudesta ja toimivuudesta, tosin vielä suppeasti.

* On saatu kokemuksia monimuoto-opetussuunnitelman laatimisesta.

* On saatu kokemuksia opiskelun ja työn yhdistämisestä, yhdistäminen on todettu hyväksi ratkaisuksi.

\section{Itseopiskelu}

* Itseopiskelu on todettu aikuiselle sopivaksi opiskelutavaksi, josta nuoret eivät samalla tavalla innostu: itseopiskelu on työlästä, mutta mielekästä ja motivoivaa.

\section{Yleistä}

* Joskus monimuoto-opetuksen keinot ovat ainoa mahdollisuus opiskeluun $\mathrm{mm}$. vammaisilla aikuisilla, harvaan asutuilla alueilla.

\section{Monimuoto-opetuksen kehittämisen nykyvaihe}

Monimuotoisten opetusmenetelmien kehittäminen kuluu opetushallituksessa opetuksen kehittämisen tulosalueeseen.

Valtioneuvoston viime marraskuussa hyväksymässä kehittämissuunnitelmassa todetaan, että aikuiskoulutuksen tarjontaa lisätään kehittämissuunnitelmakaudella ja tämä lisäys toteutetaan pääsääntöisesti jo toimivissa yksiköissä monimuoto-opetusta hyväksi käyttäen sekä tutkintojen suorittamismuotoja kehittämällä. Edelleen kehittämissuunnitelmassa todetaan, että opetuksen jär- 
jestämiseksi luodaan avoimen opetuksen järjestelmä. Tämä tarkoittaa sitä, että opetusta toteutetaan luokattomana ja samaan tutkintoon tähtäävää opetusta voivat tarjota eri organisaatiot.

Syksyllä 1991 käynnistettiin muutamilla paikkakunnilla monimuoto-opetuksen kehittämishankkeita, joista vuoden vaihteessa valittiin viisi hanketta jatkamaan toimintaansa monimuotoopetuksen ja sähköisten viestinten opetuskäytön alueellisina kehittämiskeskuksina. Pohjois-Suomen keskus sijaitsee Torniossa, Länsi-Suomen keskus Porissa, Etelä-Suomen keskus Järvenpäässä, Itä-Suomen keskus Kuopiossa ja Kaakkois-Suomen keskus Mikkelissä.

Tyypillistä näille kehittämiskeskuksille on, että ne ovat useamman oppilaitoksen yhteenliittymiä ja niissä tehdään yhteistyötä sekä ammatillisten että vapaan sivistystyön oppilaitosten kesken. Kehittämiskeskusten tehtävänä on suunnitella yhteisesti koulutustarjontaa ja vastata koulutustarpeeseen $\mathrm{mm}$. kehittämällä monimuotoisia menetelmiä ja kokeilemalla erilaisten sähköisten viestimien käyttökelpoisuutta opetuksessa.

Osaprojekteina kehittämistoimintaan liittyy sähköpostin sekä audiografiikan opetuskäytön kehittäminen. Molemmat ovat vuorovaikutuksen mahdollistavia välineitä.

Sähköposti ja sähköiset kokoukset ovat olleet oppilaitosten ja kouluttajien käytössä jo jonkin aikaa. Sähköposti sopii kokemusten mukaan yksilölliseen ajasta ja paikasta riippumattomaan opiskeluun. Sähköposti on mahdollistanut mm. hajaasutusalueiden ihmisten ja vammaisten henkilöiden opiskelun. Sähköpostin opetuskäytöstä tarvitaan lisää kokemuksia mm. oppimateriaalin siirtokysymysten ratkaisemiseksi sekä eri järjestelmien kustannusten vertailemiseksi.

Audiografiikka opetuksen apuvälineenä ei ole vielä kovin tunnettu, mutta siitä on jo saatu myönteisiä kokemuksia eräiden opetuskokeilujen yhteydessä. Audiografiikalla välitetään opetusta puhelimitse samanaikaisesti yhdelle tai useammalle ryhmälle. Puhe välitetään neuvottelupuhelimen välityksellä ja oppimateriaali visualisoidaan mikrojen kuvaruutujen avulla. Audiograafinen opetus on vuorovaikutteista ja on laajennettavissa liikkuvalla kuvalla.
Audiografiikkajärjestelmiä on Suomessa ollut lähinnä yliopistojen ja korkeakoulujen täydennyskoulutuskeskuksien käytössä. Tämän kehittämishankkeen yhteydessä on tarkoitus laajentaa käyttöä ammatillisiin ja vapaan sivistystyön oppilaitoksiin sekä hankkia tietoa menetelmän soveltuvuudesta erilaisiin opetuksellisiin ratkaisuihin.

Menetelmällisten kehittelyjen yhteydessä on tarkoitus pyrkiä etsimään taloudellisista edullisia ratkaisuja etäopetusosuuden toteuttamiseen.

Alueellisten kehittämiskeskusten lisäksi hankkeessa on mukana käsi- ja taidealojen sekä terveydenhuoltoalan monimuoto-opetuksen kehittämiskeskukset alaan liittyvine erityisine selvitystehtävineen. Mm. käsi- ja taidealoilla on erityisenä selvitystehtävänä liikkuvan kuvansiirron tekniikan kehittäminen. Kokeilun edetessä on saanut alkunsa myös kaksi kielten monimuoto-opetuksen kehittämishanketta.

Kehittämiskeskukset pitävät yhteyttä toisiinsa ja opetushallinnon edustajiin pääsääntöisesti sähköisin viestimin (sähköposti, sähköiset kokoukset, audiografiikka).

Kehittämiskeskuksilla on oman toiminnan kehittämiseen aikaa runsas vuosi. Tämän jälkeen ne ovat sitoutuneet toimimaan alueellisina tai alakohtaisina monimuoto-opetuksen ja sähköisten viestinten opetuskäytön kouluttajina ja kehittämispaikkoina: esimerkiksi opettajat voivat tehdä tutustumiskäyntejä haluamaansa kehittämiskeskukseen ja saada opastusta laitteiden käytössä, materiaalin laatimisessa tms. Kehittämiskeskukset keräävät koko ajan tietoa toiminnan kehittymisestä raportointia varten; raportointi tapahtuu sekä kehittämiskeskuskohtaisesti että kehittämisteemoittain. Toiminnasta on syntymässä joitakin yliopistollisia opinnäytetöitäkin.

Muuta tietoa kehittämiskeskushankkeen alusta ja edistymisestä voi saada lähiaikoina ensi kerran ilmestyvästä tiedotuslehdestä, josta on tarkoitus kehittää neljä kertaa vuodessa julkaistava monimuoto-opetuksen keskustelufoorumi. Tässä vaiheessa kokeilijat keskustelevat suljetulla sähköisellä ilmoitustaululla, mutta viimeistään syksyllä on tarkoituksena aloittaa avoimen ilmoitustaulun toiminta. 